\title{
Methanol intoxication, lentiform fork sign, plasma methanol and osmolar gap
}

\author{
Intoxicação por metanol, sinal do lentiforme (garfo), metanol plasmático e gap osmolar \\ Pathum Sookaromdee ${ }^{1}$, Viroj Wiwanitkit ${ }^{2}$
}

Dear Editor,

We found the report on "Acute methanol poisoning" very interesting. The clinical image of this patient may confirm that he has the neurological problem due to metabolic acidosis. The neuroimaging finding in this patient may be a case with lentiform fork sign that is nonspecific for methanol intoxication ${ }^{2}$. With the lack of a good complete clinical history, it is difficult to judge whether the case is an actual neurological problem due to methanol poisoning. The important concern is on the laboratory parameters of the patient. The high plasma methanol level, but normal osmolar gap, should be discussed. The plasma methanol concentration reported could be fatal for the patient and the osmolar gap should not be normal. In methanol intoxication, the normal osmolar gap might be possible but the plasma methanol should not high ${ }^{3}$. The cause of high methanol has also been reported to be a false positive in patients with ketoacidosis or hyperglycemia ${ }^{4,5}$. The alcoholic ketoacidosis may present with a false positive high plasma methanol, acidosis with a normal osmolar gap and lentiform fork sign.

\section{References}

1. Villamar MF. Acute methanol poisoning. Arq Neuropsiquiatr. 2018 Sep;76(9):636-7. https://doi.org/10.1590/0004-282×20180060

2. Grasso D, Borreggine C, Perfetto F, Bertozzi V, Trivisano M, Specchio LM, et al. Lentiform fork sign: a magnetic resonance finding in a case of acute metabolic acidosis. Neuroradiol J. 2014 Jun;27(3):288-92. https://doi.org/10.15274/NRJ-2014-10041

3. Hovda KE, Hunderi OH, Rudberg N, Froyshov S, Jacobsen D. Anion and osmolal gaps in the diagnosis of methanol poisoning: clinical study in 28 patients. Intensive Care Med. 2004 Sep;30(9):1842-6. https://doi.org/10.1007/s00134-004-2373-7
4. Górska A, Zaleski K, Zapalska-Pozarowska K, Szponar J. [Difficulties in interpreting the results of laboratory tests for methanol concentration in serum of patients with metabolic acidosis of various origins]. Przegl Lek. 2012;69(8):595-8. Polish.

5. Renom G, Maisonneuve N, Kim I, Dehon B, Azar R. Major ketogenesis and the absence of an osmolar gap in an atypical case of alcoholic ketoacidosis. Ann Clin Biochem. 2003 Jul;40(Pt 4):424-6. https://doi.org/10.1258/000456303766477110

\footnotetext{
${ }^{1}$ TWS Academic Center, Bangkok Thailand;

${ }^{2}$ Adjunct professor, Joseph Ayobabalola University, Ikeji-Arakeji, Nigeria.

Pathum Sookaromdee (iD) https://orcid.org/0000-0002-8859-5322

Viroj Wiwanitkit (iD https://orcid.org/0000-0003-1039-3728

Correspondence: Pathum Sookaromdee;TWS Academic Center, Bangkok Thailand; Email: pathumsook@gmail.com

Conflict of interest: There is no conflict of interest to declare.

Received 30 October 2018; Accepted 28 November 2018.
} 